\title{
Assessment of the effect of methionine supplementation and inclusion of hydrolyzed wheat protein in milk protein-based milk replacers on the performance of intensively fed Holstein calves
}

\author{
J. J. Castro, ${ }^{*}$ G. H. Hwang, ${ }^{*}$ A. Saito,† D. A. Vermeire,‡ and J. K. Drackley*1 \\ *Department of Animal Sciences, University of Illinois, Urbana 61801 \\ †Zen-Raku-Ren, Tokyo, Japan 108-0014 \\ $\ddagger$ Nouriche Nutrition, Lake St. Louis, MO 63367
}

\section{ABSTRACT}

The objectives of this study were to compare 2 milk replacers containing only milk proteins with or without supplemental Met, and to compare a milk replacer containing hydrolyzed wheat protein at $4.5 \%$ of dry matter (DM) and supplemental Lys and Met against the 2 all-milk-protein formulas, by assessing their effect on the growth performance, efficiency, and plasma urea nitrogen of pre-weaning Holstein calves. Thus, 57 Holstein calves were allotted to the following 3 treatments: (1) a skim milk plus whey protein concentrate-based milk replacer (SMWP) containing about $2.6 \%$ Lys and $0.6 \%$ Met on a DM basis; (2) SMWP + M based on skim milk and whey proteins, containing about $2.6 \%$ Lys, and supplemental Met to reach $0.9 \%$ on a DM basis; and (3) a skim milk plus whey protein concentrate plus $4.5 \%$ of the DM as hydrolyzed wheat protein based milk replacer (HWP + LM) where the wheat protein replaced $50 \%$ of the whey protein concentrate, and also contained supplemental Lys and Met to match the profile of SMWP + M (i.e., Lys 2.6 and Met $0.9 \%$ on DM basis). No difference in any of the responses was observed by supplementing the milk protein based formula with Met or when hydrolyzed wheat protein was added to the formula. Results indicate that (1) a milk replacer based on skim milk protein and whey protein with a Lys concentration of $\sim 2.6 \%$ does not benefit from Met supplementation, and (2) milk replacer containing $4.5 \%$ of the DM as hydrolyzed wheat protein and supplemented with Lys and Met can support the same growth performance as milk protein-based formulas.

Key words: amino acid, calf, lysine, methionine, wheat

Received November 3, 2015.

Accepted March 31, 2016.

${ }^{1}$ Corresponding author: drackley@illinois.edu

\section{INTRODUCTION}

Milk proteins are considered the best protein source for the young calf due to their high digestibility, balanced AA profile, and the absence of anti-nutritional factors. However, milk protein sources are the most expensive to formulate milk replacers due to an ever increasing use for human consumption (Davis and Drackley, 1998). Alternative, more economical protein sources are needed.

Wheat protein is one alternative that has undergone improvement over the years, going from raw wheat gluten, which exhibits lower digestibility than milk proteins and contains antinutritional factors that negatively affect the intestinal epithelium (Kilshaw and Slade, 1982), to acid hydrolyzed wheat protein (HWP) that is rid of any antigenic activity, has greater digestibility, and displays enhanced water solubility (De Laporte and Demeersman, 1991). Feeding trials have shown that HWP can partially replace and perform as well as milk proteins in milk replacers. Ortigues-Marty et al. (2003) observed no differences in live weight gain or carcass yield of male veal calves when HWP was substituted for $50 \%$ of the milk proteins in $22 \% \mathrm{CP}$ milk replacers. However, these researchers used 4-wk-old calves, which are more capable of digesting various nonmilk proteins compared with newborns (Ternouth et al., 1976; Davis and Drackley, 1998; NRC, 2001). Other reports (Terui et al., 1996) also indicate that HWP at $50 \%$ of the milk replacer CP supports performance at least as well as a $100 \%$ milk protein-based formulas when CP concentrations are about 18 to $20 \%$. Nevertheless, these calves were fed limited amounts of milk replacer, which resulted in extremely low BW gains (0.19 to $0.27 \mathrm{~kg} / \mathrm{d}$ ) suggesting that perhaps energy and not AA was limiting. Therefore, information is still limited as to whether HWP can support rapid growth and if supplementation with whey protein or crystalline AA is required to provide a more complete AA profile to maintain high growth performance of intensively fed newborn calves (Davis and Drackley, 1998). 
Table 1. Initial body size measurements by treatment ${ }^{1}$

\begin{tabular}{lccccc}
\hline Variable & SMWP & SMWP + M & HWP + LM & SE & $P$-value \\
\hline Number of calves & 20 & 18 & 19 & & \\
BW, kg & 41.98 & 41.30 & 42.71 & 1.26 & 0.71 \\
Heart girth, cm & 80.23 & 80.88 & 81.13 & 0.91 & 0.54 \\
Body length, cm & 58.55 & 58.25 & 59.55 & 1.17 & 0.89 \\
Withers height, cm & 77.55 & 78.35 & 78.00 & 0.80 & 0.81 \\
Hip height, cm & 81.68 & 81.80 & 82.13 & 0.86 & 0.44 \\
Hip width, cm & 17.41 & 17.43 & 17.63 & 0.29 & 0.62 \\
\hline
\end{tabular}

${ }^{1}$ SMWP $=$ skim milk and whey protein concentrate-based milk replacer (all milk diet); SMWP $+\mathrm{M}=\mathrm{SMWP}$ supplemented with Met (all milk diet plus Met); HWP + LM = milk replacer based on dried skim milk plus $\mathrm{WPC}+4.5 \%$ hydrolyzed wheat protein plus Lys and Met.

On the other hand, it has been suggested that Lys and Met are actually low in milk proteins, that they can be limiting in calves (Hill et al., 2008a,b), and that addition of crystalline Lys and Met to achieve about 2.34 and $0.72 \%$ of $\mathrm{DM}$, respectively, in milk proteinbased milk replacers could improve calf performance (Hill et al., 2008b).

The objective of this study was 2-fold: (1) to compare milk replacers containing only milk proteins and Lys at $\sim 2.6 \%$ of DM with and without supplemental Met, and (2) to compare a milk replacer containing HWP at $4.5 \%$ of DM containing Lys at $\sim 2.6 \%$ of $\mathrm{DM}$ and supplemented with Met, against the 2 all-milk-protein formulas by assessing their effect on the growth performance, efficiency, and plasma nitrogen of preweaning Holstein calves.

\section{MATERIALS AND METHODS}

\section{Calves, Management, and Treatments}

The experiment was conducted at the University of Illinois Dairy Cattle Research Unit with Holstein calves born on the unit. All experimental protocols were approved by the Institutional Animal Care and Use Committee at the University of Illinois. The experiment was conducted from May 2012 through February 2013. Animals were enrolled in the study as they were born throughout the 9-mo period. Calves were allotted to the following 3 treatments: (1) a dried skim milk and whey protein concentrate (WPC)-based milk replacer (SMWP) containing about $2.6 \%$ Lys and $0.6 \%$ Met on a DM basis (20 calves), (2) SMWP supplemented with Met (SMWP $+\mathbf{M}$ ) to reach $0.9 \%$ on a DM basis (18 calves), and (3) a milk replacer based on dried skim milk plus WPC plus 4.5\% HWP (HWP + LM) where HWP replaced $50 \%$ of the WPC and comprised approximately $13 \%$ of the total $\mathrm{CP}$ concentration, and also contained supplemental Lys and Met to match the profile of SMWP + M (i.e., Lys 2.6 and Met $0.9 \%$ on DM basis; 20 calves). Originally, a fourth treatment containing no WPC and 9\% HWP plus supplemental
Lys and Met to match the profile of SMWP + M was to be evaluated, but correct Lys and Met concentrations were not attained during manufacturing and hence these data are not presented.

A similar number of females and males were randomly assigned to each of the 3 experimental diets. Initially we aimed to complete 20 calves per treatment but due to concurrent experiments and calving schedules it was not possible to enroll 20 calves in treatment SMWP + M. One calf from treatment HWP + LM died during experimental wk 2 from diarrhea, but no necropsy was conducted. Otherwise, no mortality and no systematic illness episodes were registered for any treatment. Table 1 illustrates the homogeneity of the animals across diets upon treatment allotment.

After receiving colostrum, calves were housed in individual hutches bedded with straw. Fresh water was available at all times and replaced daily. Calves were fed only milk replacer (Milk Specialties Global Animal Nutrition, Eden Prairie, MN) twice daily from d 2 through d 28 of life, when starter (Vita Plus, Madison, WI) was introduced. We considered that allowing calves to have access to milk replacer only during the first month of life would allow a less variable determination of the protein source effects by avoiding any unknown potential interactions with grain intake. Milk replacer powder was fed at a rate of $600 \mathrm{~g} / \mathrm{d}$ (DM basis) during wk $1,800 \mathrm{~g} / \mathrm{d}$ during wk 2, 1,200 g of DM/d during wk 3 to $5,800 \mathrm{~g} / \mathrm{d}$ during wk 6 , and $600 \mathrm{~g} / \mathrm{d}$ during wk 7 , reconstituted at $15 \% \mathrm{DM}$.

\section{Sampling and Analysis}

Intakes of milk replacer and starter were recorded daily. Measurements of BW, withers height, hip height, body length, and heart girth were performed weekly until d 56 (weaning). Cumulative ADG, and efficiencies of feed DM, Lys, and Met use for gain were calculated from cumulative growth, calf age, and nutrient intake.

Milk replacer samples were collected weekly, composited by month, and sent to the University of Missouri for 
Table 2. Nutrient composition of milk replacer formulas ${ }^{1}$

\begin{tabular}{lccccc}
\hline Nutrient, $\%$ & SMWP & SMWP + M & HWP + LM & SE & $P$-value \\
\hline DM & 96.8 & 96.9 & 97.0 & 0.13 & 0.29 \\
CP & 28.7 & 29.0 & 28.8 & 0.17 & 0.38 \\
Crude fat & 16.1 & 15.5 & 16.0 & 0.54 & 0.76 \\
Ash & $8.2^{\mathrm{a}}$ & $7.7^{\mathrm{b}}$ & $7.8^{\mathrm{b}}$ & 0.04 & 0.0001 \\
Ca & $0.98^{\mathrm{a}}$ & $0.92^{\mathrm{b}}$ & $0.92^{\mathrm{b}}$ & 0.01 & 0.01 \\
P & $0.85^{\mathrm{a}}$ & $0.77^{\mathrm{b}}$ & $0.78^{\mathrm{b}}$ & 0.01 & 0.0001 \\
Lys & 2.59 & 2.62 & 2.57 & 0.06 & 0.88 \\
Met & $0.57^{\mathrm{b}}$ & $0.89^{\mathrm{a}}$ & $0.96^{\mathrm{a}}$ & 0.05 & 0.0001 \\
Met:Lys & 0.22 & 0.34 & 0.37 & - & - \\
\hline
\end{tabular}

${ }_{\mathrm{a}, \mathrm{b}}$ Different superscripts indicate statistical difference at $\alpha=0.05$.

${ }^{1} \mathrm{SMWP}=$ skim milk and whey protein concentrate-based milk replacer (all milk diet); SMWP $+\mathrm{M}=\mathrm{SMWP}$ supplemented with Met (all milk diet plus Met); HWP + LM = milk replacer based on dried skim milk plus $\mathrm{WPC}+4.5 \%$ hydrolyzed wheat protein plus Lys and Met.

${ }^{2}$ Met to Lys ratio. Computed from Met and Lys concentrations but not tested statistically.

analysis of Lys and Met concentrations and to DairyOne (Ithaca, NY) for analyses of proximal constituents, $\mathrm{Ca}$, and P. Starter samples composited by month were analyzed by DairyOne for DM, CP, soluble protein, ADF, NDF, lignin, NFC, crude fat, ash, Ca, and P. The nutrient profiles of milk replacers and starter are described in Tables 2 and 3.

Blood samples were collected from a jugular vein after $48 \mathrm{~h}$ of colostrum feeding (before treatments) and then at 1, 3, 5, and $7 \mathrm{wk}$. Blood plasma samples were obtained $3 \mathrm{~h}$ pre- and postfeeding. Plasma and serum samples were maintained frozen at $-20^{\circ} \mathrm{C}$ until analysis of total protein by refractometry and blood urea nitrogen by urease-based colorimetry, respectively, at the diagnostic laboratory of the Veterinary Medicine College of the University of Illinois.

\section{Statistical Analysis}

Performance and blood urea and protein data were analyzed according to a repeated measures design with age, treatment, age by treatment interaction, month of birth, and sex as fixed effects. Body measures at birth

Table 3. Nutrient composition of grain starter

\begin{tabular}{|c|c|c|}
\hline Nutrient & Mean & $\mathrm{SE}$ \\
\hline DM, \% & 88.4 & 0.18 \\
\hline $\mathrm{CP}, \%$ of $\mathrm{DM}$ & 21.8 & 0.50 \\
\hline $\mathrm{ADF}, \%$ of $\mathrm{DM}$ & 13.4 & 0.89 \\
\hline $\mathrm{NDF}, \%$ of DM & 24.1 & 0.75 \\
\hline Lignin, \% of DM & 5.2 & 0.45 \\
\hline NFC, $\%$ of DM & 43.6 & 1.22 \\
\hline Ash, $\%$ of DM & 7.2 & 0.09 \\
\hline TDN & 75.0 & 0.45 \\
\hline $\mathrm{ME}, \mathrm{Mcal} / \mathrm{kg}$ & 1.94 & 0.07 \\
\hline $\mathrm{NE}_{\mathrm{M}}, \mathrm{Mcal} / \mathrm{kg}$ & 1.6 & 0.02 \\
\hline $\mathrm{NE}_{\mathrm{G}}, \mathrm{Mcal} / \mathrm{kg}$ & 1.1 & 0.02 \\
\hline $\mathrm{Ca}, \%$ of $\mathrm{DM}$ & 1.0 & 0.02 \\
\hline $\mathrm{P}, \%$ of $\mathrm{DM}$ & 0.9 & 0.02 \\
\hline
\end{tabular}

and pre-feeding blood concentrations were included as covariates in the model for growth and blood urea and protein, respectively. Month of birth was included in the model as a blocking factor for seasonal effects. Repeated measurements were assumed to be correlated and thus various error covariance matrix types were evaluated to identify the one with the least number of parameters and that would minimize the adjusted Akaike information criteria and the Bayesian information criteria (Fitzmaurice et al., 2011). Also, residuals were checked for homogeneity of variance and normality by residual plots. Hence, based on the above goodness of fit criteria and due to the presence of heterogeneous variances, a first-order ante dependence [ANTE(1)] and a heterogeneous autoregressive structure (ARH1) variance covariance matrix were implemented. Both of these accommodate heterogeneous variances and allow for unequally or equally spaced observations, respectively. Significance was declared at $P<0.05$. When a difference was found to be significant, treatment means were compared by a Tukey's pairwise comparison test.

To estimate the change in performance per unit increase in HWP concentration in the milk replacer, and the dependence of this response on calf age, the following regression model was fit to the data:

$$
Y_{i j}=b_{0}+b_{1} \times H W P_{i}+b_{2} \times A g e_{j(i)} \times(H W P \times A g e)_{i j}+e_{i j}
$$

where $Y_{i j}$ is the performance repeated measure on $i$ th calf in the $j$ th week, and $H W P_{i}$ is the level of HWP in the milk formula fed to the $i$ th calf; $b_{0}, b_{1}, b_{2}$, and $b_{3}$ correspond to the intercept and the regression coefficients for HWP level, age, and their interaction, respectively. The errors $e_{i j}$ were found to be normally distributed with heterogeneous variance and assumed nonindependent for the ith calf, but independent among calves. Therefore, the above-mentioned error covariance ma- 
trices were fitted here as well. The $b_{2}$ term was significantly greater than 0 for all variables $(P<0.001)$, and except for Lys and Met intake and efficiency, where the effect of age is of biological interest, it is omitted elsewhere, along with $b_{0}$ (i.e., the intercept) whose interpretation carries meaning of no particular biological interest here. Only $b_{1}$ and $b_{3}$ are thus reported. A Kenward Roger approximation was used to compute the degrees of freedom.

\section{Fecal and Respiratory Scores}

Because the number of days with fecal or respiratory scores $>2$ did not follow a normal distribution, they were assumed to follow a Poisson distribution with expected value and variance equal to $\mu$. In this case a transformation $g$ of the expected value is described by a linear function of the predictors. Thus, the regression model was

$$
g(\mu)=\alpha+x \times \beta,
$$

where $g$ is a link function (i.e., a transformation of the expectation), in terms of a generalized linear model; $\alpha$ is the specified intercept; $x$ is the design matrix containing the independent variables including the effect of treatments, sex, and month of birth; and $\beta$ contains the model parameter estimates.

The link function was taken to be the natural log function; thus,

$$
g(\mu)=\log (\mu)=\alpha+x \times \beta .
$$

Therefore, to estimate the mean number of days with scores $>2$ after fitting the model to the data, we take the inverse of the natural log, that is, the model parameter estimates are simply exponentiated as

$$
\mu=e^{\alpha+x \times \beta} \text { or } \mu=e^{\alpha} e^{x \times \beta} \text {. }
$$

Because the variance estimate was greater than the expected number of days with high fecal scores, which is a violation of the Poisson distribution, a variance scaling parameter was estimated to adjust the parameter estimate standard errors (Fitzmaurice et al., 2011). Data for respiratory scores did not present this condition.

Restricted maximum likelihood was used to estimate the model parameters and a Wald test to assess their significance. Standardized deviance residual plots were used to assess model adequacy (Fitzmaurice et al., 2011) and the results were satisfactory.

\section{RESULTS AND DISCUSSION}

Milk replacer formulas contained similar amounts of DM, CP, and fat but SMWP + M and HWP + LM contained slightly less Ca and P than SMWP (Table 2) for unknown reasons. This difference, although statistical, was minimal and all 3 treatments were close to those of whole milk $\mathrm{Ca}(10 \mathrm{~g} / \mathrm{kg}$ of DM) and $\mathrm{P}(7.5 \mathrm{~g} / \mathrm{kg}$ of DM) concentrations and well within the recommended supply range recommended by different research groups (Ca: 7 to $13 \mathrm{~g} / \mathrm{kg}, \mathrm{P}: 5$ to 9.7 ; Davis and Drackley, 1998). Moreover, the disadvantaged treatments did not present any growth or intake depression. Because milk replacers contained about $29 \% \mathrm{CP}$ and HWP was about $81 \% \mathrm{CP}$, inclusion of $4.5 \% \mathrm{HWP}$ in the HWP + LM treatment must effectively have resulted in HWP constituting $13 \%$ of the total milk replacer CP.

With respect to Lys, all treatments presented similar concentrations ranging from 2.57 to $2.62 \%$ of DM $(P=$ 0.88 , Table 2), whereas SMWP $+\mathrm{M}$ and HWP $+\mathrm{LM}$ had greater $(P<0.01$, Table 2$)$ Met concentrations (0.89 and $0.96 \%$, respectively) than SMWP (0.57\%), with Met:Lys calculated at 0.34 and 0.37 , respectively, as originally intended. This resulted in a proportionally greater Met intake for SMWP $+\mathrm{M}$ and HWP + LM (Table $4, P<0.01$ ). However, this difference in Met intake appeared not to affect growth performance (Table $4, P>0.08$ ). As a consequence, SMWP calves displayed a greater Met efficiency compared with SMWP + M and HWP + LM (Table $4, P=0.01$ ). Otherwise, we did not observe treatment differences in milk DMI, grain DMI, total DMI, Lys intake, gain:feed, or gain:Lys. Also, no interactions were found between treatment and age, sex, or initial BW on calf growth or feed intake from wk 1 to $8(P>0.15$, Table 4$)$ with the exception of Met intake and efficiency for which the difference between nonsupplemented (SMWP) and supplemented (SMWP + M and HWP + LM) treatments was smaller during wk 1 and 2 and larger during wk 3 and 4 (weekly means not shown).

The regression coefficients for HWP level and its interaction with age were not different from 0 (Table 5) as shown in Figure 1, which illustrates the clearly linear calf growth trajectory over the first 8 wk of life and the lack of positive or negative slope from 0 to $4.5 \%$ HWP. Similar results were obtained for heart girth, body length, withers height, hip height, hip width, ADG, milk DMI, grain DMI, total DMI, Lys intake, Met intake, gain:feed, gain:Lys, and gain:Met (Table $5)$. These results indicate that (1) the milk proteinbased formula with a Lys concentration of $\sim 2.6 \%$ (i.e., SMWP diet) did not benefit from Met supplementation (i.e., Met was not limiting), and (2) at $4.5 \%$ of the DM 
Table 4. Effect of diet on average body growth, food intake (DM), and efficiency from wk 1 to 8 of life ${ }^{1}$

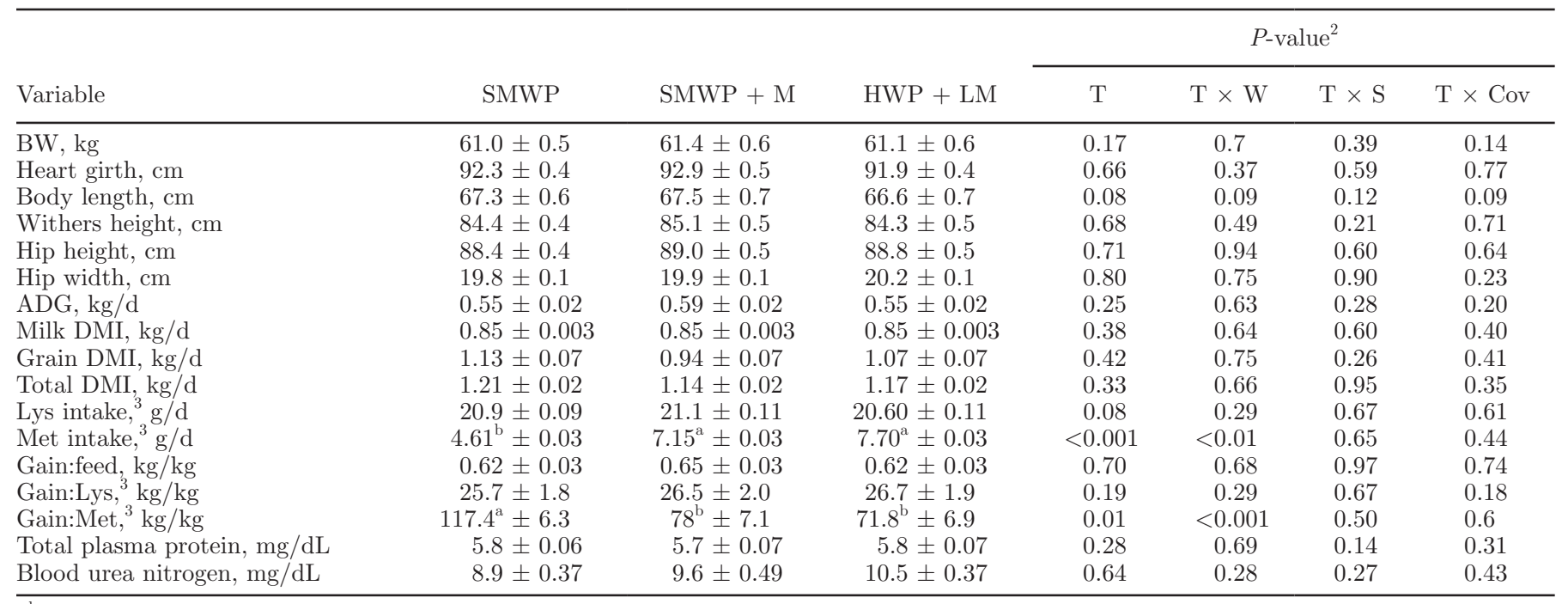

a,b Different superscripts indicate statistical difference at $\alpha 0.05$.

${ }^{1}$ SMWP $=$ skim milk and whey protein concentrate-based milk replacer (all milk diet); SMWP + M = SMWP supplemented with Met (all milk diet plus Met); HWP + LM = milk replacer based on dried skim milk plus WPC $+4.5 \%$ hydrolyzed wheat protein plus Lys and Met.

${ }^{2}$ Significance of the effects of dietary treatment effect $(\mathrm{T})$, treatment by week interaction $(\mathrm{T} \times \mathrm{W})$, treatment by sex interaction $(\mathrm{T} \times \mathrm{S})$, and treatment by initial measure covariate $(\mathrm{T} \times \mathrm{Cov})$.

${ }^{3}$ Through wk 4 only (i.e., only milk feeding period).

or $13 \%$ of the milk replacer total CP content, HWP supplemented with Lys and Met supported the same growth performance as the milk protein-based formula.

Previously, Ortigues-Marti et al. (2003) reported no differences in BW gain and feed efficiency of Holstein veal calves when comparing a milk replacer containing HWP at $15 \%$ of the DM against a milk protein-based milk replacer, of which both formulas were balanced to the same Lys concentration. In addition, when they supplemented branched-chain AA, no enhancement in growth performance was observed under the HWP diet (Ortigues-Marty et al., 2003). In that study, HWP replaced $50 \%$ of the milk proteins, whereas we only substituted $13 \%$. Direct comparison with those results is difficult, however, because they fed the HWP milk replacers when calves were 4 wk old, at which point they bear greater enzymatic and acidic ability to digest nonmilk proteins compared with newborn calves (Ternouth et al., 1976; Davis and Drackley, 1998; NRC, 2001). In another report (Terui et al., 1996), HWP included at $50 \%$ of the $\mathrm{CP}$ on a DM basis in a $20 \%$ $\mathrm{CP} / 20 \%$ fat milk replacer resulted in the same growth performance when compared with preweaning calves fed a milk replacer containing only milk proteins. No Lys was reported to have been supplemented in the HWP milk formula in that study, thus likely remaining at lower concentrations than the milk protein formula. At first sight it would appear that our study was rather conservative as we only included HWP at $13 \%$ of the total CP compared with $50 \%$ in the above study, but speculative comparisons of responses to protein or AA supply with that report are complicated as they fed milk replacer at such low levels (1.3\% of BW as DM) that energy and not AA may presumably have hindered growth as reflected in the very low BW gains (0.19 to $0.27 \mathrm{~kg} / \mathrm{d}$ ). Previous reports where $50 \%$ of dietary CP was supplied from HWP (Davis and Drackley, 1998) showed that ADG and feed efficiency were approximately $10 \%$ and 0.05 units lower, respectively, compared with milk protein-based formulas. Work elsewhere (Hill et al., 2008a) has similarly shown that feeding milk replacers containing HWP at $4.3 \%$ of DM with Lys and Met balance led to lower ADG (13\%), starter intake $(17 \%)$, and feed efficiency $(6 \%)$ compared with all milk protein-based milk replacers. Given that no AA deficiency should have taken place in the latter study, the authors hypothesized that the lower growth and efficiency response of those calves receiving the HWP diets was not related to limiting nutrients but likely due to poor ability of calves to fully digest and absorb plant proteins. This hypothesis is supported by research (Branco-Pardal et al., 1995; Toullec and Formal, 1998) showing that partially replacing milk proteins by HWG lowered ileal apparent digestibility in calves by 4 to $7 \%$, which could be associated with resistant peptides rich in glutamic acid and proline residues. In our case, however, balancing for Lys and Met concentrations to be similar or greater in the HWP diet compared with the 
Table 5. Regression coefficients for hydrolyzed wheat protein (HWP) level and its interactions with calf age

\begin{tabular}{|c|c|c|c|}
\hline Parameter & Estimate & $\mathrm{SE}$ & $P$-value \\
\hline \multicolumn{4}{|l|}{ BW } \\
\hline $\mathrm{HWP}^{1}$ & 0.09 & 0.17 & 0.61 \\
\hline $\mathrm{HWP} \times \mathrm{Wk}^{2}$ & 0.0006 & 0.006 & 0.92 \\
\hline \multicolumn{4}{|l|}{ Heart girth } \\
\hline HWP & -0.55 & 0.86 & 0.52 \\
\hline $\mathrm{HWP} \times \mathrm{Wk}$ & -0.0012 & 0.005 & 0.8 \\
\hline \multicolumn{4}{|l|}{ Body length } \\
\hline HWP & -2.00 & 1.31 & 0.13 \\
\hline $\mathrm{HWP} \times \mathrm{Wk}$ & -0.0015 & 0.007 & 0.83 \\
\hline \multicolumn{4}{|l|}{ Wither height } \\
\hline HWP & -0.10 & 0.91 & 0.91 \\
\hline $\mathrm{HWP} \times \mathrm{Wk}$ & -0.0042 & 0.0043 & 0.34 \\
\hline \multicolumn{4}{|l|}{ Hip height } \\
\hline HWP & -0.09 & 0.90 & 0.91 \\
\hline $\mathrm{HWP} \times \mathrm{Wk}$ & -0.003 & 0.0041 & 0.47 \\
\hline \multicolumn{4}{|l|}{ Hip width } \\
\hline HWP & 0.09 & 0.21 & 0.67 \\
\hline $\mathrm{HWP} \times \mathrm{Wk}$ & 0.0010 & 0.0012 & 0.41 \\
\hline \multicolumn{4}{|l|}{$\mathrm{ADG}$} \\
\hline HWP & 0.024 & 0.04 & 0.57 \\
\hline HWP × Wk & 0.0003 & 0.0003 & 0.25 \\
\hline \multicolumn{4}{|l|}{ Grain DMI } \\
\hline HWP & 0.005 & 0.05 & 0.92 \\
\hline $\mathrm{HWP} \times \mathrm{Wk}$ & -0.001 & 0.01 & 0.89 \\
\hline \multicolumn{4}{|l|}{ Milk DMI } \\
\hline HWP & -0.009 & 0.08 & 0.90 \\
\hline $\mathrm{HWP} \times \mathrm{Wk}$ & 0.0002 & 0.003 & 0.95 \\
\hline \multicolumn{4}{|l|}{ Total DMI } \\
\hline HWP & -0.014 & 0.008 & 0.09 \\
\hline $\mathrm{HWP} \times \mathrm{Wk}$ & 0.00008 & 0.0009 & 0.93 \\
\hline \multicolumn{4}{|l|}{ Met intake } \\
\hline HWP & 0.09 & 0.52 & 0.85 \\
\hline $\mathrm{HWP} \times \mathrm{Wk}$ & 0.003 & 0.027 & 0.9 \\
\hline \multicolumn{4}{|l|}{ Lys intake } \\
\hline HWP & -0.27 & 0.4 & 0.48 \\
\hline $\mathrm{HWP} \times \mathrm{Wk}$ & -0.007 & 0.05 & 0.88 \\
\hline \multicolumn{4}{|l|}{ Gain:feed } \\
\hline HWP & -0.005 & 0.03 & 0.88 \\
\hline $\mathrm{HWP} \times \mathrm{Wk}$ & 0.002 & 0.002 & 0.22 \\
\hline \multicolumn{4}{|l|}{ Gain:Lys } \\
\hline HWP & 1.40 & 3.00 & 0.64 \\
\hline $\mathrm{Wk}^{3}$ & 3.97 & 0.73 & $<0.0001$ \\
\hline $\mathrm{HWP} \times \mathrm{Wk}$ & 0.017 & 0.28 & 0.95 \\
\hline \multicolumn{4}{|l|}{ Gain:Met } \\
\hline HWP & 3.23 & 13.8 & 0.81 \\
\hline $\mathrm{Wk}^{3}$ & 18.96 & 2.55 & $<0.0001$ \\
\hline $\mathrm{HWP} \times \mathrm{Wk}$ & -1.39 & 0.99 & 0.16 \\
\hline \multicolumn{4}{|l|}{ Blood urea N } \\
\hline HWP & -0.16 & 0.71 & 0.82 \\
\hline $\mathrm{HWP} \times \mathrm{Wk}$ & -0.05 & 0.03 & 0.13 \\
\hline
\end{tabular}

${ }^{1}$ Regression coefficient for HWP level.

${ }^{2}$ Regression coefficient for the interaction HWP by week.

${ }^{3}$ Regression coefficient for calf age in weeks.

SMWP diet resulted in similar performance in calves fed large amounts of DM and growing rapidly, thus the lower ileal digestibility hypothesis may apply only conditionally under certain circumstances.

From our feeding schedule, it is possible to calculate that calves were fed daily an average of $0.950 \mathrm{~kg} / \mathrm{d}$ (DM) during the first $4 \mathrm{wk}$ of life. At observed CP, Lys, and Met concentrations of about 29, 2.59, and
$0.57 \%$ DM in the SMWP diet, the respective average nutrient intakes must have been approximately 275,25 , and $5.41 \mathrm{~g} / \mathrm{d}$, with a concomitant observed ADG, Lys efficiency, and Met efficiency of around $0.89 \mathrm{~kg} / \mathrm{d}, 38$ $\mathrm{g}$ of BW gain/g of Lys, and $165 \mathrm{~g}$ of BW gain/g of Met (data not shown for first $4 \mathrm{wk}$ ). Hill et al. (2008b) reported maximal ADG of $0.46 \mathrm{~kg} / \mathrm{d}$ with $\mathrm{CP}$, Lys, and Met intakes of 204, 17, and $5.3 \mathrm{~g} / \mathrm{d}$, respectively, for calves fed about $0.65 \mathrm{~kg}$ of $\mathrm{DM} / \mathrm{d}$ of a $26 \% \mathrm{CP} / 17$ fat milk replacer. Based on those findings, Hill et al. (2008b) established a requirement for calves less than 5 wk old averaging $48 \mathrm{~kg}$ of BW and fed $0.65 \mathrm{~kg}$ of $\mathrm{DM} / \mathrm{d}$ to be met with $17 \mathrm{~g} / \mathrm{d}$ of Lys and 0.31 Met:Lys. From their data it is possible to calculate their Lys and Met efficiency must have been around 27 and $87 \mathrm{~g}$ of BW gain per g of Lys and Met, respectively. Therefore, it appears that calves in the present study attained an approximately 93\% higher ADG, 40\% higher Lys efficiency, and 90\% higher Met efficiency with 35, 47, and $2 \%$ greater CP, Lys, and Met intakes and Met:Lys at 0.21 . A major difference in the 2 studies was the feeding rate, which in the case of Hill et al. (2008b) was set at $0.65 \mathrm{~kg}$ of $\mathrm{DM} / \mathrm{d}$ compared with $0.95 \mathrm{~kg}$ of $\mathrm{DM} / \mathrm{d}$ on average for the first $4 \mathrm{wk}$ in our study. Thus, the $0.27 \mathrm{~kg}$ of $\mathrm{DM} / \mathrm{d}$ additional intake in our study likely led calves to be responsive to the additional AA supply (Schroeder and Titgemeyer, 2008; Zanton and Heinrichs, 2008). Hence, the requirements suggested by Hill et al. (2008b) with CP, Lys, and Met at 204, 17, and $5.3 \mathrm{~g} / \mathrm{d}$ likely are specific to their particular feeding rates. To have more certainty of the overall response to AA or digestible protein intake by the young preruminant calf, the independent effect of energy needs to be simultaneously taken into consideration during future research.

Figure 2 displays the rapid evolution in total DMI from 1 to 8 wk of life and a concomitant increase in variability among calves. Yet, there is no positive or negative slope going from 0 to $4.5 \%$ HWP in the milk replacer indicating that at $4.5 \%$ of the milk replacer DM, the HWP + LM diet did not affect DMI compared with the SMWP and SMWP + M diets. Also, the effect of age was independent of HWP level $(P>0.05$, Tables 4 and 5). Some of the referenced reports found that HWP can result in greater nutrient intake from wk 4 to 13 of age (Ortigues-Marty et al., 2003), and from wk 1 to 7 of age (Terui et al., 1996), although a null effect of HWP on nutrient intake has also been observed (Hill et al., 2008a).

One possible cause of lack of growth response to supplemental Met might be the lower energy density due to the lower fat concentration of these milk replacers compared with more conventional formulas including at least $20 \%$ fat. Yet, there is evidence that with milk 


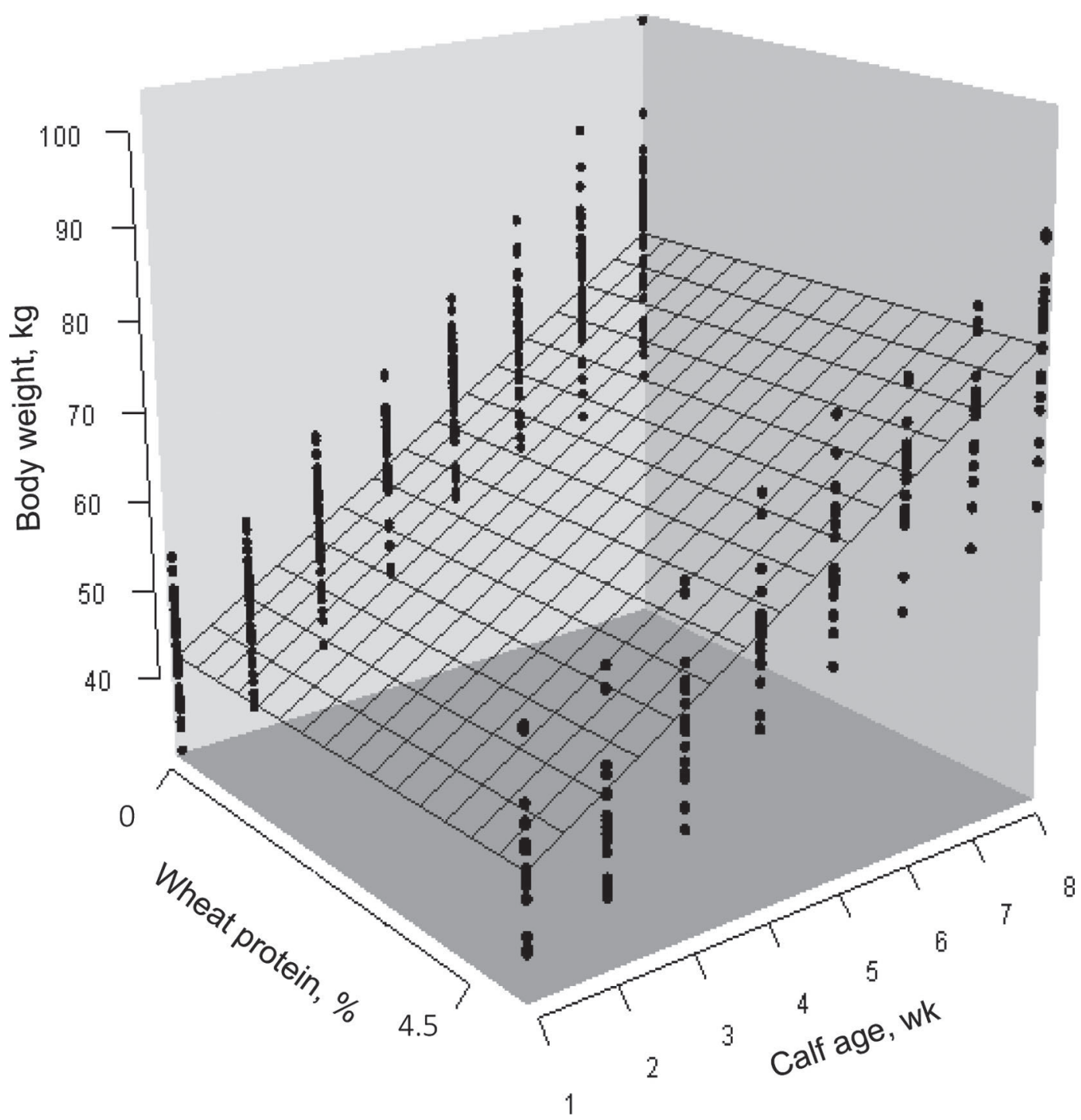

Figure 1. Relationship among calf age, wheat protein level, and BW (kg).

replacers similar to those used in our study and fed at similar rates, increasing fat beyond $15 \%$ fat at the expense of lactose does not lead to greater lean tissue deposition but mostly adipose retention (Tikofsky et al., 2001).

Despite the lack of response to Met supplementation, calf age appeared to have a preponderant effect on Lys and Met efficiency. Figure 3 shows a positive slope of Lys efficiency (3.97 g of BW gain:g of Lys intake per wk, $P<0.001$, Table 5) from wk 0 to 4 , which suggests a rapid increase of about $20 \%$ per week in Lys use efficiency in calves with respect to the initial value at wk 1 (20 g of BW/g of Lys/d, data not shown). Likewise, an increase of $18.96 \mathrm{~g}$ of BW:g of Met per wk was observed from 0 to $4 \mathrm{wk}$ of age. This positive linear increase in ADG:Lys or ADG:Met per wk of age is in contrast with observations from others (Zanton and Heinrichs, 2008), where the amount of $\mathrm{N}$ retained per unit of $\mathrm{N}$ intake starts to decrease as the calf matures from about birth weight (see Figure 5 in their report). Those authors carried out a comprehensive quantitative literature review with data covering the BW range between 40 and $80 \mathrm{~kg}$ of BW in milk-fed calves receiving a $\mathrm{N}$ supply from 0 to $3 \mathrm{~g} / \mathrm{kg}$ of $\mathrm{BW}^{0.75}$ daily and retaining from 0.25 to $1 \mathrm{~g}$ of $\mathrm{N} \mathrm{kg}$ of $\mathrm{BW}^{0.75}$ daily. At an approximate average $\mathrm{BW}$ of $55.4 \mathrm{~kg}$ or $7.8 \mathrm{~kg}$ of $\mathrm{BW}^{0.75}$, a $\mathrm{CP}$ intake of $285 \mathrm{~g} /$ calf per d during the first 4 wk of age (data not shown), and an assumed CP digestibility of $95 \%$, the $\mathrm{N}$ intake of our calves must have been about $2.1 \mathrm{~g}$ of $\mathrm{N} / \mathrm{kg}$ of $\mathrm{BW}^{0.75} / \mathrm{d}$, hence within the range of their study (Zanton and Heinrichs, 2008). We did not measure $\mathrm{N}$ retention, but if we assume that ADG in 


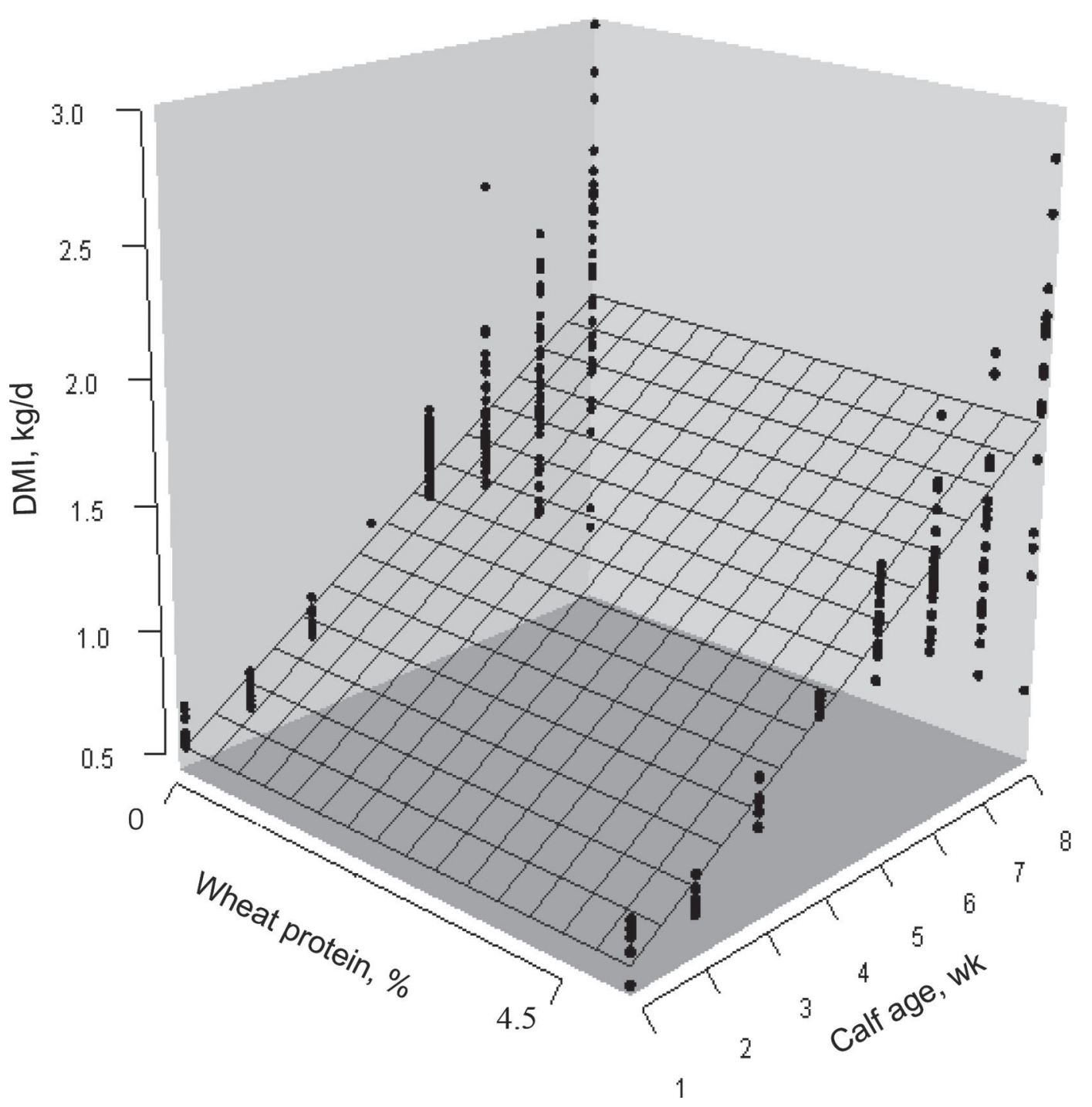

Figure 2. Relationship among calf age, wheat protein level, and total DMI (kg/d).

our study mostly represented lean mass and not fat deposition, the equation that explained their data best would not predict the linear increase in lean mass gain efficiency with calf age that was observed here. If there was indeed such an increase in $\mathrm{N}$ efficiency in the first 3 or 4 wk of age, it might be that newborn calves need to develop their internal organs more and adapt to their environment better before muscle tissue develops full affinity for arterial AA and these are partitioned more toward growth. Although we observed the calves in our experiment remained very lean and we suspect ADG was indeed mostly lean mass, it is possible that fat deposition accounted for some portion of ADG and that $\mathrm{N}$ retention per unit of Lys or Met was indeed decreasing from 0 to $4 \mathrm{wk}$ of age. Evidently, further assessment of growth responses to $\mathrm{N}$ or AA supply and profile in newborn dairy calves under intensified feeding programs is needed to define maximal capacity of $\mathrm{N}$ retention and hence AA requirements from 0 to $4 \mathrm{wk}$ of age.

The increased Lys or Met efficiency with age did not depend on HWP dietary level $(P=0.95$ and $P=$ 0.16 , Table 5). Figure 3 also shows the absence of a relationship between Lys efficiency and HWP level as illustrated by a rather flat regression line $(P=0.64)$ from 0 to $4.5 \%$, indicating that Lys and Met supplemented HWP milk replacer can sustain the same Lys use efficiency for BW gain as a 100\% milk proteinbased formula. Blood urea $\mathrm{N}$ concentrations align with this observation since means for SMWP, SMWP + Met, and HWP + Met were similar $(P=0.64$, Table 4 ) and the regression coefficient for HWP level was not 


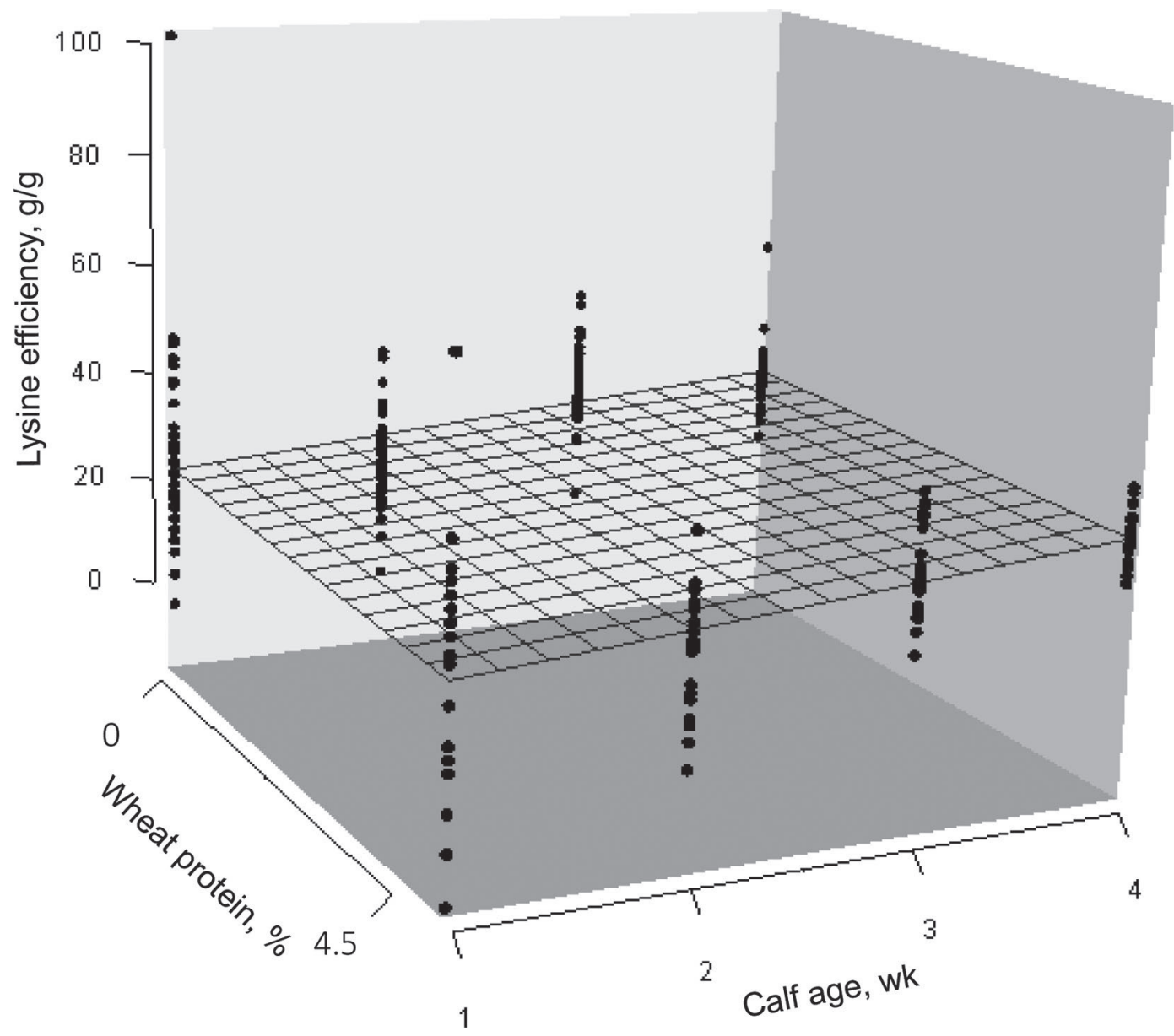

Figure 3. Relationship among calf age, wheat protein level, and Lys efficiency (g of BW/g of Lys).

different from $0(P=0.82$, Figure 4$)$, suggesting that postabsorptive AA metabolism and the resulting $\mathrm{N}$ efficiency was unaffected by HWP at $4.5 \%$ of the milk replacer DM. No interactions of diet with age or sex were observed on blood urea nitrogen $(P>0.05$, Tables 4 and 5). Total blood protein concentration was also not different between dietary treatments $(P>0.05$, Table 4 ), and neither were the interactions with age or sex (Table 4).

No treatment effects on the mean number of days with fecal scores $>2$ were found $(P=0.9$, Table 6$)$. Overall, the estimated number of days with high fecal scores ranged between 10.3 and 11.2, whereas high respiratory score days were close to zero $(P=0.53$, Table 6).

\section{CONCLUSIONS}

The objective of this experiment was to compare the performance of pre-weaning calves intensively fed milk replacers containing protein from either milk origin only

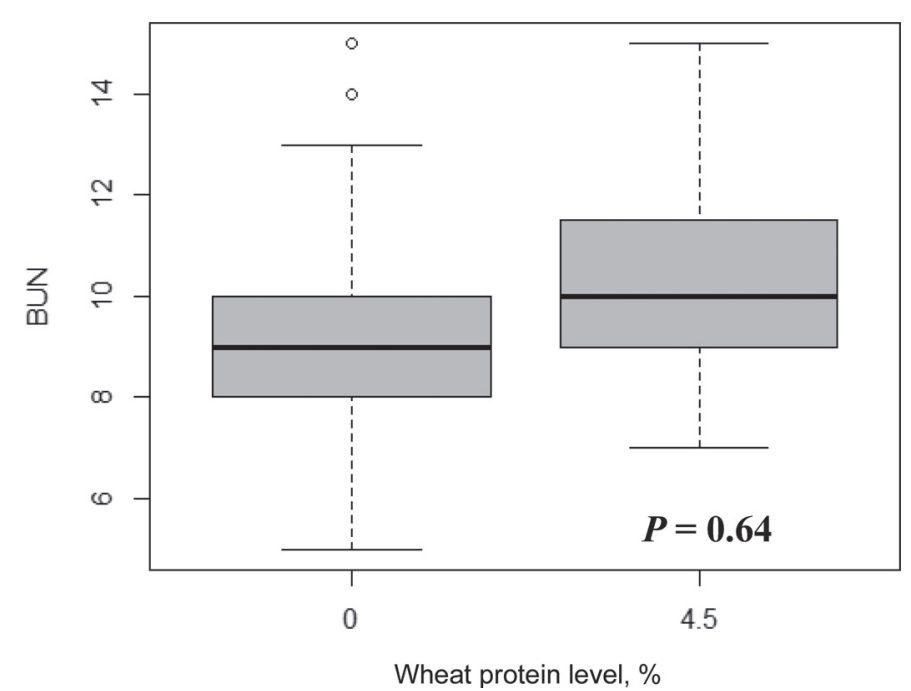

Figure 4. Distribution of BUN data from calves fed all milk or milk plus wheat proteins milk replacers. Lower- and uppermost bars are minimum and maximum values, respectively, excluding outliers (०); upper and lower box sides are 25th and 75th percentiles, and solid horizontal line is the median or 50th percentile. 
Table 6. Treatment effect on the average number of weeks with fecal and respiratory scores $>2^{1}$

\begin{tabular}{|c|c|c|c|c|}
\hline Item & SMWP & $\mathrm{SMWP}+\mathrm{M}$ & $\mathrm{HWP}+\mathrm{LM}$ & $P$-value ${ }^{2}$ \\
\hline \multicolumn{5}{|l|}{ Fecal score } \\
\hline $\begin{array}{l}\mu_{\text {Fecal score }}^{3} \\
\exp ^{\mu}{ }_{\text {Fecal }}\end{array}$ & $\begin{array}{l}2.4 \pm 0.09 \\
10.9\end{array}$ & $\begin{array}{l}2.4 \pm 0.09 \\
11.2\end{array}$ & $\begin{array}{l}2.3 \pm 0.1 \\
10.3\end{array}$ & 0.9 \\
\hline \multicolumn{5}{|l|}{ Respiratory score } \\
\hline $\begin{array}{l}\mu_{\text {Respiratory score }} \\
\exp ^{\mu}{ }_{\text {Respiratory }}\end{array}$ & $\begin{array}{c}-1.6 \pm 0.5 \\
0.2\end{array}$ & $\begin{array}{c}-1.1 \pm 0.4 \\
0.3\end{array}$ & $\begin{array}{c}-0.8 \pm 0.4 \\
0.4\end{array}$ & 0.53 \\
\hline
\end{tabular}

${ }^{1} \mathrm{SMWP}=$ skim milk and whey protein concentrate-based milk replacer (all milk diet); SMWP $+\mathrm{M}=\mathrm{SMWP}$ supplemented with Met (all milk diet plus Met); HWP + LM = milk replacer based on dried skim milk plus WPC $+4.5 \%$ hydrolyzed wheat protein plus Lys and Met.

${ }^{2}$ Probability of observing current estimates by chance alone.

${ }^{3}$ Poisson parameter estimate.

${ }^{4}$ Estimated number of weeks with fecal or respiratory scores $>2$.

with and without addition of supplemental Met, or from HWP at $4.5 \%$ of DM with addition of supplemental Lys and Met. In general, milk protein-based milk replacer did not benefit from Met supplementation, supporting the concept that milk proteins already provide an adequate supply of Met. Also, the diet containing 4.5\% HWP supplemented with AA performed similarly to milk protein-based milk replacers. Our findings indicate the suitability of HWP as a partial alternative protein source for milk replacers for calves at high rates of gain when AA are balanced to milk profiles.

\section{ACKNOWLEDGMENTS}

The authors are grateful for funding of this project from Zen-Raku-Ren, (Tokyo, Japan) and Nouriche Nutrition Ltd. (Lake St. Louis, MO).

\section{REFERENCES}

Branco-Pardal, P., L. J. Fau, M. F. Formal, P. F. Guilloteau, and R. Toullec. 1995. Digestion of wheat gluten and potato protein by the preruminant calf: Digestibility, amino acid composition and immunoreactive proteins in ileal digesta. Reprod. Nutr. Dev. 35:639-654.

Davis, C. L., and J. K. Drackley. 1998. The Development, Nutrition, and Management of the Young Calf. 1st ed. Iowa State University Press, Ames.

De Laporte, A., and M. Demeersman. 1991. Soluble wheat protein in milk replacer for veal calves. Pages $222-226$ in New Trends in Veal Calf Production. Vol. 52. J. H. Metz and C. Groenestein, ed. Wageningen, the Netherlands.
Fitzmaurice, G. M., N. M. Laird, and J. H. Ware, ed. 2011. Applied Longitudinal Analysis. 2nd ed. John Wiley \& Sons, Hoboken, NJ.

Hill, T. M., H. G. Bateman II, J. M. Aldrich, and R. L. Schlotterbeck. 2008a. Effects of using wheat gluten and rice protein concentrate in dairy calf milk replacers. Prof. Anim. Sci. 24:465-472.

Hill, T. M., H. G. Bateman II, J. M. Aldrich, R. L. Schlotterbeck, and K. G. Tanan. 2008b. Optimal concentrations of lysine, methionine, and threonine in milk replacers for calves less than five weeks of age. J. Dairy Sci. 91:2433-2442.

Kilshaw, P. J., and H. Slade. 1982. Villus atrophy and crypt elongation in the small intestine of preruminant calves fed with heated soyabean flour or wheat gluten. Res. Vet. Sci. 33:305-308.

NRC. 2001. Nutrient Requirements of Dairy Cattle. 7th rev. ed. The National Academies Press, Washington, DC.

Ortigues-Marty, I., H. J. Fau, G. F. Bertrand, C. F. Martineau, M. F. Vermorel, and R. Toullec. 2003. The incorporation of solubilized wheat proteins in milk replacers for veal calves: Effects on growth performance and muscle oxidative capacity. Reprod. Nutr. Dev. 43:57-76.

Schroeder, G. F., and E. C. Titgemeyer. 2008. Interaction between protein and energy supply on protein utilization in growing cattle: A review. Livest. Sci. 114:1-10.

Ternouth, J. H., J. H. B. Roy, and S. M. Shotton. 1976. Concurrent studies of the flow of digesta in the duodenum and of exocrine pancreatic secretion of calves. Br. J. Nutr. 36:523-535.

Terui, H., J. L. Morrill, and J. J. Higgins. 1996. Evaluation of wheat gluten in milk replacers and calf starters. J. Dairy Sci. 79:12611266.

Tikofsky, J. N., M. E. Van Amburgh, and D. A. Ross. 2001. Effect of varying carbohydrate and fat content of milk replacer on body composition of Holstein bull calves. J. Anim. Sci. 79:2260-2267.

Toullec, R., and M. Formal. 1998. Digestion of wheat protein in the preruminant calf: Ileal digestibility and blood concentrations of nutrients. Anim. Feed Sci. Technol. 73:115-130.

Zanton, G. I., and A. J. Heinrichs. 2008. Analysis of nitrogen utilization and excretion in growing dairy cattle. J. Dairy Sci. 91:1519 1533 . 